\title{
Mechanization in sugarcane production and other agricultural activities: an econometric analysis of employment and income
}

\author{
Mecanização na produção de cana-de-açúcar e outras atividades \\ agrícolas: uma análise econométrica do emprego e da renda
}

\author{
Diogo Ferraz ${ }^{1,2,3}$ (1), Fabíola Cristina Ribeiro de Oliveira, ${ }^{4,5}$, \\ Daisy Aparecida do Nascimento Rebelatto ${ }^{6}$ (1), Andreas Pyka ${ }^{1}$ \\ ${ }^{1}$ Universität Hohenheim, Lehrstuhls für Innovationsökonomik, Stuttgart, Deutschland \\ ${ }^{2}$ Universidade Federal de Ouro Preto - UFOP, Departamento de Economia (DEECO), Mariana, MG, Brasil \\ "Universidade Estadual Paulista "Júlio de Mesquita Filho" - UNESP, Departamento de Engenharia de Produção, Bauru, \\ SP, Brasil. E-mail: diogoferraz@alumni.usp.br \\ ${ }^{4}$ Universidade de São Paulo - USP, Escola Superior de Agricultura "Luiz de Queiroz" - ESALQ, Piracicaba, SP, Brasil \\ ${ }^{5}$ Pontifícia Universidade Católica de Campinas - PUC, Campinas, SP, Brasil \\ ${ }^{6}$ Universidade de São Paulo - USP, Escola de Engenharia de São Carlos - EESC, Departamento de Engenharia de \\ Produção, São Carlos, SP, Brasil
}

How to cite: Ferraz, D., Oliveira, F. C. R., Rebelatto, D. A. N., \& Pyka, A. (2021). Mechanization in sugarcane production and other agricultural activities: an econometric analysis of employment and income. Gestão \& Produção, 28(4), e5768. https://doi.org/10.1590/1806-9649-2021v28e5768

\begin{abstract}
Several studies argue that agricultural mechanization has reduced employment and wages. However, there is a lack of studies analyzing employment and income over time, especially comparing the agricultural activities. Our major argument is the structural change in the employment - from un-skilled to skilled workers which has to be understood because of the overall decrease in the number of jobs. This study aims to analyze the labor market evolution in sugarcane farming and other agricultural activities, from 1992 to 2015. Using the National Household Sample Survey (PNAD/IBGE), we compared sugarcane and other Brazilian crops using econometrics techniques. We analyzed the Heckman's procedure and models with fixed effects panel data, controlling the unobservable characteristics of workers. Methodologically, our equations show convergence, since the Heckman procedure and pooled regression present similar estimates. We showed that fixedeffect regression captures the same trends of Ordinary Least Square (OLS) technique, using the Heckman method. Our main findings suggest that the wage of sugarcane workers is higher than wages in other crops, even after we control the observable and regional characteristics. This finding is important because the sugarcane sector has faced criticism regarding the low level of employment and income due to the mechanization process. Finally, we pointed out the decrease in unskilled jobs in sugarcane, which demands for policy intervention to improve the human capital in the sugarcane sector.
\end{abstract}

Keywords: Agriculture; Sugarcane sector; Brazil; Econometrics; Heckman's Model.

Resumo: Vários estudos argumentam que a mecanização agrícola reduziu o emprego e os salários. No entanto, faltam estudos que analisem o emprego e a renda ao longo do tempo, principalmente comparando as atividades agrícolas. $O$ argumento apresentado por este artigo é que a mudança estrutural no emprego - de trabalhadores não qualificados para qualificados, deve ser entendida por

Received Nov. 24, 2019 - Accepted Oct. 13, 2020

Financial support: Coordenação de Aperfeiçoamento de Pessoal de Nível Superior (CAPES) (Process no.. 88887.161388/2017-00).

This is an Open Access article distributed under the terms of the Creative Commons Attribution License, which permits unrestricted use, distribution, and reproduction in any medium, provided the original work is properly cited. 
causa da diminuição geral do número de empregos. Este estudo tem como objetivo analisar a evolução do mercado de trabalho na lavoura canavieira e demais atividades agrícolas, de 1992 a 2015. Por meio da Pesquisa Nacional por Amostra de Domicílios (PNAD / IBGE), este artigo compara a cultura da cana-de-açúcar com outras lavouras brasileiras por meio de técnicas econométricas. Analisamos o procedimento e os modelos de Heckman com dados de painel de efeitos fixos, controlando as características não observáveis dos trabalhadores. Metodologicamente, nossas equações mostram convergência, uma vez que o procedimento de Heckman e a regressão combinada apresentam estimativas semelhantes. Note que a regressão de efeito fixo captura as mesmas tendências da técnica de Mínimos Quadrados Ordinários (MQO), usando o método de Heckman. Os principais resultados sugerem que o salário dos trabalhadores da cana-de-açúcar é maior do que o salário de outras safras, mesmo depois de controlar as características observáveis e regionais. Essa constatação é importante porque o setor sucroalcooleiro tem enfrentado críticas quanto ao baixo nível de emprego e renda devido ao processo de mecanização. Por fim, destacamos a diminuição do número de empregos não qualificados na cana-de-açúcar, o que exige intervenção de políticas para a melhora do capital humano no setor sucroalcooleiro.

Palavras-chave: Agricultura; Setor sucroalcooleiro; Brasil; Econometria; Modelo de Heckman.

\section{Introduction}

Over the last two decades, the Brazilian sugarcane industry has undergone many institutional changes, such as the sector's deregulation and prohibition of burning sugarcane in the harvesting process, producing clear adaptations on the sectoral organization and labor market. Several studies indicate that sectoral liberalization has generated relatively positive effects, for example, higher efficiency and lower production costs in agriculture and agroindustry (Alves, 2007; Moraes, 2007a; Figueira et al., 2013; Ferraz et al., 2019).

According to Alves (2007), after deregulation, sugarcane companies adopted strategies based on a new organizational and production arrangement associated with the new political view of Brazilian authorities after the 1990s. In other terms, Brazil opened its economy to achieve international competitiveness, which affected the country's legislation, thus impacting the sugarcane sector. For example, in the state of Sao Paulo, the environmental legislation (State Law n. 11.241, 2002) (São Paulo, 2002) advocates reducing impacts and damage on public health. This law recommends agricultural areas to gradually reduce sugarcane burns through mechanization process. Although the environmental policy recommends ending the burning by 2021, local authorities have postponed the end of burning until 2031 in non-mechanized areas.

Moraes (2007a) argues that in several regions in Sao Paulo, harvest mechanization had already been carried out before the law was implemented. Producers adopted mechanization due to economic and labor advantages, such as low costs and higher productivity. In this sense, in 2005, the share of sugarcane mechanization was higher than manual harvesting, which met the percentage stipulated by the law. It is noteworthy that the sugarcane area in the state of Sao Paulo (estimated at almost 8 million hectares) is representative since it covers $60 \%$ of the total Brazilian sugarcane extension (Novaes et al., 2016).

In addition, in June 2007 an Agro-Environmental Protocol (São Paulo, 2007) was signed in the state of Sao Paulo, involving the Secretariat of the Environment (SMA), the Secretariat of Agriculture and Supply (SAA), the Sugarcane Industry Association (União da Indústria de Cana-de-Açúcar) (UNICA), the Organization of Cane Producers Association (Organização de Plantadores de Cana da Região Centro-Sul do Brasi) (ORPLANA) in the Center-South Region of Brazil, to ensure sustainability of the sugar, ethanol, and bioenergy production chain. According to this protocol, Sao Paulo sugarcane 
producers must anticipate the end of sugarcane burning. In lands with a slope of up to $12 \%$, the exit date is moved forward from 2021 to 2014 . In lands with a slope above $12 \%$, the exit is moved forward from 2031 to 2017 . Some studies have estimated compliance with this protocol. Novaes et al. (2016), using a spatial analysis method, found that there were clusters where adherence to the protocol was greater, while in other areas burning practices are still prevailing. The prescriptive model presented by the authors indicated that, at the end of the period stipulated by this protocol, the regions analyzed would correspond to more or less $80 \%$ to the extinction of the sugarcane harvest burning.

Furthermore, some studies analyzed the impact of institutional and structural changes on labor relations (Moraes, 2007a; Oliveira, 2009). Some studies suggest that the mechanization of the sugarcane sector reduces unskilled employment, workers' health conditions, and introduce working conditions similar to slavery. Some other studies argue that sugarcane mechanization decreases labor income and the number of employed people, especially unskilled workers, which might increase unemployment in agriculture.

This study sheds light on the impact mechanization has on the income and employment of workers in the sugarcane sector. Our research question is whether mechanization has positively affected employment and labor income in the sugarcane sector. Our major argument is the structural change in the employment - from un-skilled to skilled workers which has to be understood because of the overall decrease in the number of jobs. In this sense, this study aims to analyze the labor market evolution in sugarcane farming, compared with other agricultural activities, from 1992 to 2015 . Our hypothesis is that mechanization process may positively affect employment and labor income in Brazil, which would contradict studies that argue against the mechanization process. In addition, we estimate the wage differentials based on the income of the main work of employed persons (salaried) in sugarcane and other crops by means of income equations (Mincer's wage equation).

This study presents some theoretical and methodological contributions. First, there is no consensus on the impact of mechanization on agriculture and the reduction or increase in employment as well as labor income. For this reason, our findings are important because, despite the criticism regarding the low level of employment and income due to the mechanization process in the sugarcane sector, the wage of sugarcane workers is higher than wages in other crops, even after we control the observable and regional characteristics. Second, this study provides a methodological contribution, since we show that fixed-effect regression captures the same trends of Ordinary Least Square (OLS) technique, using the Heckman method. Third, we analyze the sugarcane sector, which in 2015 represented $22.3 \%$ of Gross Domestic Product (GDP) and $38 \%$ of employment in Brazil (IBGE, 2019). Additionally, Brazil is the largest worldwide sugar producer and exporter (Shikida et al., 2010; Brasil, 2016). Brazil is the world's leading sugar producer and exporter, accounting for approximately half of the global business of this commodity (Moraes \& Zilberman, 2014). Brazil accounts for $44.8 \%$ of the global production, followed by Thailand $(9.7 \%)$, Australia $(6.3 \%)$ and Guatemala $(2.9 \%)$, which are the other main global producers, respectively (Agra Europe, 2010; Neves et al., 2016). During the 2014/2015 harvest, national sugar output reached 35.548 million tons (UNICA, 2016). Production in the Center-South (90\%) was higher than in the North-Northeast (10\%) and Sao Paulo state $(61.6 \%$ total) was the main productive region. Due to the domestic and international sugarcane importance, our study reveals strategies to modernize also other agricultural activities in Brazil, as well as current improvements in sugarcane mechanization in other countries.

This work is divided into five parts. The introduction is followed by a literature review about institutional change and a depiction of the data on the sugar market in Brazil as well 
as in other parts of the globe. The third section introduces the methodology. The fourth section discusses our findings through the statistical tests and the econometric models. The study ends with section 5 presenting the final remarks.

\section{Sugarcane: institutional changes, production, and labor market}

There are several studies analyzing the Brazilian state intervention and its impact on agriculture (Moraes, 2002; Figueira et al., 2013; Moraes \& Zilberman, 2014; Ramos \& Belik, 2019; Ferraz et al., 2019;). The sugarcane sector is one of the most regulated agricultural activities. According to Moraes (2002), from 1930 to 1980, public authorities intervened in the production process, administrative organization, and strategies to achieve higher productivity and competitiveness. Decisions were made exploiting information on production, consumption, and export of the sugarcane sector.

According to Ramos \& Belik (2019), state interventions occurred in several ways. In 1931 , federal authorities obliged the federal units to collect $10 \%$ of sugar production to maintain regulatory stocks. In 1941, the Sugar and Alcohol Institute (Instituto de Açúcar e Álcool- IAA) established feedstock quotas for each sugarcane mill. Moreover, sugarcane mills had quotas to produce sugar, according to the state plan to offer adequate supply to the economy. After 1960, sugarcane mills were associated with new investors, which changed negotiations with IAA, which reduced the IAA strategy to promote development of the regional sugarcane sector. In addition, during the 1960s, Brazilian export increased due to favorable international market conditions. Brazil exported $15 \%$ of the sugarcane production, which summed up to $3.5 \%$ of the international sugar business. In this sense, Brazilian production was led by the state of Sao Paulo, which determined new rules for the national sugarcane sector.

Moraes (2002) argues that the Brazilian state has reduced public intervention due to the financial crises during the 1980s. Trough economic liberalization and privatizations during the 1990s, Brazilian authorities expected that globalization and commercial opening could increase productivity, which also should boost production and income. However, refineries in the state of São Paulo still today struggle with innovation in terms of improved productivity in the agro-industrial processes (Moraes \& Zilberman, 2014). Due to the economic liberalization and the new political agenda, the Brazilian economy underwent a deregulation process. This process has continued throughout the 1990s, and in 1999 the sugarcaneethanol industry was finally deregulated (Moraes \& Zilberman, 2014).

It is noteworthy to emphasize that after the state stopped intervening in the sugarcane sector, the relationship between the agents of the production chain was altered. The selling costs were determined by free trade, allowing for positive effects, e.g. raising efficiency and decreasing the costs in both agricultural and industrial sectors (Figueira et al., 2013). The harvest mechanization and the loading and transport system of sugarcane ensured rapid supply to the refineries, increasing maintenance of the sucrose content of the raw material. The automated control in the industrial processes guaranteed the quality of sugar and ethanol, and the deregulation has allowed Brazilian sugar to become more competitive on global markets (Moraes \& Zilberman, 2014).

The reply to the new scenario came along with new ways to communicate the sugar supply to transnational companies. First of all, the most competitive sugar companies set up strategic alliances with the foreign capital, i.e., by means of investing in production diversification or in complementary activities in port terminals. Second, less competitive sugar companies formed alliances with other companies to foster investments in the agricultural/logistical operations flow to the port terminals and the sugar crop supply. Finally, direct purchase of sugar 
companies or the shareholding interest in sugar company groups added value to the new scenario, which corroborates the professionalization of the sector. This happened because the new environment transformed the management of the companies: previously administrated by families, the management was profoundly professionalized. This has contributed to reduced production costs and increased efficiency of sugarcane milling, as well as in sugar and ethanol production (Moraes \& Zilberman, 2014).

Since 2002, the Brazilian sugarcane sector has improved its international competitiveness with two products - sugar and alcohol. The increasing competitiveness is explained by several determinants: First, the increased national and international demand. Second, petroleum prices increased, which was essential to increase the share of ethanol in Brazil. Third, the flex-fuel car technology increased the demand of ethanol in Brazil, which guarantees the local consumption of ethanol. Fourth, the Kyoto Protocol imposed the reduction of greenhouse gases, corroborating the expansion of alcohol consumption. Fifth, the alcohol production in the United States of America was not sufficient to meet its internal market. Sixth, the Center-South region in Brazil increased its productivity reducing production costs, which makes the sugarcane sector one of the worldwide most competitive (Alves, 2007; Moraes, 2007b).

However, this prominent scenario also affected labor relations. In order to increase productivity, fulfill labor legislation, and reduce environmental issues, public authorities stimulated the agricultural mechanization process, in particular in sectors which easily can replace manual harvest. Moraes (2007b) pointed out two crucial institutional changes that encourage mechanization in the sugarcane sector. First, the state of Sao Paulo anticipated the deadline for eliminating the burning of sugarcane. Second, producers must meet new labor rules, for example the Regulatory Regulation 31, which established new organization modes and proposed changes in the work environment in the agricultural sector. These institutional changes strongly encouraged the sugarcane sector to adopt mechanized processes, reducing the number of jobs and demanding for skilled rather than unskilled workers.

In this sense, Oliveira (2009) shows that agricultural employment not only decreased in the sugarcane sector, but also in other agricultural activities in the 1990s. Surprisingly, however, from 2003 to 2006, sugarcane employment increased due to the expansion of harvesting areas, especially in the Brazilian Midwest region, and the favorable economic conditions of this sector. Interestingly, Oliveira (2009) distinguishes between skilled and unskilled employees, thereby revealing on the one hand, the low number of skilled workers in the sugarcane sector, on the other hand, however, that skilled jobs grow relatively faster than unskilled jobs. This result evidences that over the last decade the number of skilled workers has increased in the sugarcane sector, even after the mechanization process.

Complementary to the employment growth analysis, other studies investigated labor income in agriculture (Corrêa, 1998; Balsadi, 1996; Ney \& Hoffmann, 2003; Mori, 2008; Cás \& Ferreira, 2007; Cunha, 2008). Oliveira (2009) and Oliveira \& Hoffmann (2011) proceeded by analyzing the income differences between employees of the sugarcane sector and other agricultural activities. It has to be mentioned, that these authors used the Ordinary Least Square (OLS) technique, which received some criticism (Greene, 2011; Horrace \& Oaxaca, 2006; Certo \& Semadeni; 2006).

Finally, Arbache (2000) recommends that studies regarding income differences are relevant due to their contribution to the theoretical debate. Moreover, these studies corroborate policy recommendations to ensure increased employability, to improve labor income by reducing inequality, as well as to decrease regional and social heterogeneity in Brazil. The next section presents the method used to analyze employment and income in the sugarcane sector and other agricultural activities. 


\section{Method}

\subsection{Database}

We used the microdata of the National Household Sample Survey (Pesquisa Nacional por Amostra de Domicílios - PNAD), published by the Brazilian Institute of Geography and Statistics (Instituto Brasileiro de Geografia e Estatística (IBGE, 2019), for 1992 to 1993, 1995 to 1999, 2001 to 2009 and 2011 to 2015. This data contains information about people employed in Brazilian agriculture. For some years (1994, 2000, and 2010), the PNAD was not surveyed due to exceptional reasons and the Demographic Censuses.

According to IBGE (2006), an employee is a person who works for an employer with a formal or informal contract in the enterprise. Usually, an employee is obliged to work daily during some hours for the company, which guarantees the salary or alternative payments, such as products or services. Note that this study excludes other labor categories, such as self-employed people, employers, own-account employees and non-wage workers. This classification was previously used by Oliveira (2009) and Oliveira and Hoffmann (2011).

Based on the concept of agriculture, data were collected on people who carry out activities in the fields investigated by PNAD, including temporary and permanent workers. However, this study did not include the information of people living in rural or urban areas who worked in the reference week, with a single or main activity in livestock, forestry, plant extraction, fishing, and fish farming. In addition, according to Oliveira \& Hoffmann (2011), the subset of those working in establishments whose main activity was sugarcane, coffee, corn, manioc (or cassava), rice and soybeans (or only soy) is also highlighted. These cultures were chosen because there is individualized information, and because it is possible to perform comparison over time.

Furthermore, as previous done by Oliveira \& Hoffmann (2011), we classified workers into two groups. First, the unskilled workers, which refer to labor force of manual activity workers, such as collectors, brush cutters, rural workers, work with hoes. Second, skilled workers are those working on supervision activities and controlling machines. The PNAD allows us to divide these groups using some occupational codes. Using the PNAD from 1992 to 2001, we used the code V99906 to classify skilled (classification number 303) and unskilled (classification number 304) workers. Using the PNAD after 2002, we used the code V99906 (6201, 6410, 6420, and 6430) to classify skilled workers, and V99906 (6210 and 6229) to classify unskilled workers.

In addition, to carry out comparable income for different years, it will be expressed in Brazilian Reais currency in August 2016, using the National Consumer Price Index (Índice Nacional de Preços ao Consumidor) (INPC) as the deflator. This was defined, as proposed by Corseuil \& Foguel (2002), because the appropriate index was obtained by calculating the geometric mean between the INPC values of September and October. Also according to these authors, as of July 1994, the INPC was corrected incorporating an additional variation of $22.25 \%$, associated with the currency change in the Plano Real.

\subsection{Econometric model}

The income equations for employees in Brazilian agriculture were adjusted by the Ordinary Least Squares (OLS), pooled regression, fixed effects (FE) and random effects (RE) method, using the Heckman procedure (Heckman, 1979) and by means of Panel Data methods. 
The procedure proposed by Heckman (1979) was adopted in order to correct the possible problem of sample selectivity. The procedure consists of estimating two equations. The first one determines the individual's decision whether or not to participate in the labor market through a probit equation by the maximum likelihood method to obtain the estimate of the inverse ratio of Mills ${ }_{\left(\lambda_{i}\right)}$ (Greene, 2011). The equation that determines the sample selection is given by equation (1):

$Z_{i}^{*}=\partial^{\prime} W_{i}+u_{i}$

Where $z_{i}^{*}$ is the difference between the income of the main job of person $\mathrm{i}$, and their reserve wage, and $w_{i}$ is the vector of characteristics considered in this study that affect $z_{i}^{*}$. The equation (2) of initial interest is:

$y_{i}=\beta^{\prime} X_{i}+\varepsilon_{i}$

Where $y_{i}$ is observed only when $z_{i}^{*}$ is greater than zero. Supposing that $\varepsilon_{i}$ and $u_{i}$ have a bivariate normal distribution with zero mean and correlation $\rho$. Then, for each sample selected, we calculate the inverse Mill ratio, as presented by equation (3):

$\lambda_{i}=\frac{\varnothing\left(\partial^{\prime} W_{i}\right)}{\theta\left(\partial^{\prime} W_{i}\right)}$

which takes into account the probability of individuals participating in the labor market, where $\varnothing$ is the probability density function and $\theta$ is the cumulative distribution function. The relevance of the Heckman procedure is verified when analyzing the significance of the coefficient of the lambda variable and the consistency of the model as a whole through the significance of the chi-square test.

For using the panel data technique, in Brazil, there is no research that follows the same individual over time, which hinders the direct application of these techniques (Sachsida et al., 2004). The alternative found by studies of this nature is the assembly of a pseudo panel. Deaton (1985) demonstrated that it is possible to aggregate a series of cross-section data into cohorts, defined according to the individuals' year of birth, considering in each group the observed means. Then, the pseudo panel assumes a similar form as the original panel method, but with observations for the cohorts, rather than observations for individuals.

Therefore, in the present study, six cohorts were prepared in the sample, which consisted of dividing the sample for each year into six cross-section units, defined in: unit 1: individuals aged 15 to 20 years; unit 2: individuals aged 21 to 30 years; unit 3 : individuals aged 31 to 40 years; unit 4 : individuals aged 41 to 50 years; unit 5 : individuals aged 50 to 60 years; unit 6 : individuals over 61 years of age.

In this analysis, the dependent variable $(Y)$ is the logarithm of the main labor income of employed persons according to age classes, Brazilian agriculture, sugarcane plantations and other activities of the sector in the period 1992 to 2015. The specification proposed to estimate the determinants of income of employees in sugarcane and other agricultural activities is given by equation (4): 
where $y_{i t}$ is the income of the main work of the $\mathrm{i}$-th cohort $(i=1, \ldots, 6)$ in the Brazilian agriculture sector in year $\mathrm{t}(t=2001, \ldots, 2015)$. There are $\mathrm{k}$ explanatory variables in $x_{i t}^{\prime}$, not including the constant term. The heterogeneity or individual effect of each cohort of individuals is represented by $z_{i} \alpha$, where $z_{i}$ contains a constant term and a set of specific variables, which can be observed or not observed.

This article also employs grouped least-squares method or pooled regression, fixed effects (FE) and random effects (RE) to estimate the wage differentials obtained between sugar cane workers and other selected activities for this study. The pooled method stacks the data and obtains estimates of the parameters by Ordinary Least Squares (OLS); the fixed effect panel removes the influence of the unobserved factor before the parameter estimation; while the random effect panel considers that the unobserved effect is uncorrelated with all the explanatory variables included in the model (Greene, 2011).

Assuming that $z_{i}$ can be observed for all cohorts and, therefore, there are no effects of the characteristics of the unobservable workers, it means that $z_{i} \alpha$ will contain only the constant term so that the pooled regression will provide consistent and efficient estimates by the Ordinary Least Squares (OLS). However, if $z_{i}^{\prime}$ non-observable effects, the estimates of $\beta$ 's will be biased and inconsistent because of the clear problem of the omitted variable. If so, the most appropriate models will be those that have the possibility of controlling the unobservable heterogeneity.

According to Greene (2011), if unobservable heterogeneity is correlated with $x_{i t}$, it is recommended to adopt a fixed-effects model. However, if the non-observable state heterogeneity exists but is not correlated with the exogenous variables employed in the equation, the random-effects model is more appropriate. The choice of the most appropriate model is made based on the Hausman test results (see Greene (2011), which will be discussed later in the results section of the econometric models.

The decision by the most appropriate estimation method was made in two steps:

- First, the Breusch-Pagan Lagrange Multiplier test, which supports the hypothesis of the presence of unobservable random effects. In other words, the test rejects the null hypothesis of the absence of specific effects at $1 \%$ significance;

- When proving the existence of specific effects, the Hausman specification test was used to assist in the choice between the random effect method or the fixed-effect method. With the test result it was possible to reject the null hypothesis $\left(\mathrm{H}_{0}\right.$ : there is no correlation between $u_{i t}$ and $x_{i t}^{\prime}$ ). This implies that the best method to be employed is that of fixed effects.

In general, the following explanatory variables will be considered:

a) A dummy variable for gender, which assumes value 1 for females and 0 for males;

b) Five dummies to distinguish six levels of education: illiterate or less than one year of schooling (baseline), one to three years of schooling, four to seven years of schooling, eight to 10 years of schooling, 11 to 14 years of schooling and 15 years or more of schooling;

c) In order to distinguish the different wages resulting from the number of hours worked per week, three dummies variables were employed: 15 to 39 hours (base), 40 to 44 hours, 45 to 48 hours and 49 hours or more;

d) A variable to distinguish formal employees (base) and informal employees;

e) Three dummies to distinguish the color skin of the person: white (base), AfroAmerican, Asian and indigenous; 
f) Four dummies to distinguish the five major regions of the country: North, Northeast (base), South, Southeast, Midwest and also Sao Paulo state;

g) Binaries to distinguish the different segments of activity: sugarcane (base), coffee, manioc, corn, soybean, rice and other agricultural activities (excluding crops used individually);

h) A dummy to distinguish whether the employment is permanent (base) or temporary. Notably, rural and urban workers have different natures, since urban employment of the workforce takes the traditional form of permanent work, while in the rural area, the work mode is typically affected by seasonality;

i) In order to evaluate the effect of institutional factors on wages, the real value of the minimum wage will be used on the prices of August 2016. Studies conducted in the last decade show that real wage increases impact wages in Brazilian agriculture (Oliveira \& Hoffmann, 2011).

In particular, in the model adjusted according to the procedure of Heckman (1979), will be used as a proxy of the contribution of workers' training and experience for the variable age measured as follows:

k) The age of the person, measured in tens of years.

I) The square of the variable age $(R)$, considering that income does not vary linearly with age. If the parameters for age and age squared are indicated by $\dot{e ̀}_{1}$ and $\dot{e}_{2}$, respectively, one should have $\grave{e}_{1}>0$ and $\dot{e}_{2}<0$ and then the expected value of $Y$ (and income) will be maximum when the age of the individual corresponds to $\varphi_{1} /\left(2 \varphi_{2}\right)$.

The variables that make up the selection equation are the same as those used as controls in the income equation, except for the variables in the activity sector and occupation position, since such characteristics can only be observed if the individual declares himself busy in the week of the PNAD. In addition, we added to the selection equation some variables that present certain personal and family characteristics that affect the probability that the individual is working, but do not directly affect the income of those that work:

m) The conjugal status, which assumes value 1 when the individual has a spouse and value 0 if he/she does not have a spouse;

n) A dummy was included to distinguish the person who has a child and the person who has no child (base);

o) A binary to distinguish the individual's condition in the family: head of the family versus another position in the family;

p) The existence of other sources of income besides the main activity, in which the dummy variable assumes value 1 if the individual has this source and 0 if he/she does not have it.

\section{Results and discussions}

\subsection{Labor market}

This subsection presents descriptive data on the sugarcane labor market and other agricultural activities. The presented figures were built with the same database used to econometrically analyze the sugarcane and other sectors. Figure 1 illustrates the evolution in the number of employees in the sugarcane and other agricultural activities from 1992 to 2015. 


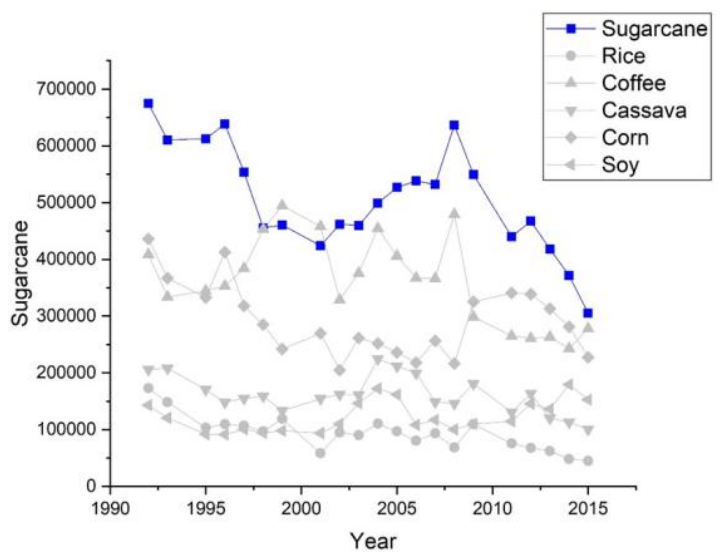

Figure 1. Number of employees ${ }^{(1)}$ in sugarcane and other agricultural activities.Source: Prepared using the data of the (IBGE, 2019); ${ }^{(1)}$ Only people with a positive value declaration for the main work income.

Despite a period of relative growth of jobs, between 1999 and 2008, there is a general trend, as observed in some studies (Oliveira, 2009), about the reduction and/or elimination of thousands of jobs in the sugarcane sector. At both ends of the series, there was a decrease of almost 370 thousand jobs in the country's sugar plantation, which corresponded to $-54.7 \%$. This development reflects the intensification of mechanization, especially in the sugarcane harvest stage.

The reduction in the number of employees is not a phenomenon exclusive to sugarcane cultivation since a similar trend is observed in agriculture as a whole, for example, between 1992 and 2015 there was a reduction of 1.4 million employees. This is equivalent to a variation of $-43.1 \%$. Other agricultural activities, with the exception of soybeans, also had high reductions in the contingent workers: rice $(-74,02)$, manioc $(-51,02)$, corn $(-47,75)$ and coffee $(-32,02)$.

The labor market reveals two phenomena. First, the mechanization process affects both employment and production in the sugarcane sector. Figure 2 illustrates the decreasing number of total employees and the increasing sugarcane production. From 1992 to 1999, sugarcane production positively varied more than 37\%. From 2001 to 2009, this variation increased to $121 \%$, from 307 million tons in 1998/1999 to 569 million tons in 2008/2009. The production growth affects the generation of jobs, despite the decreasing number of new jobs due to the mechanization process, and the 2008 international crisis.

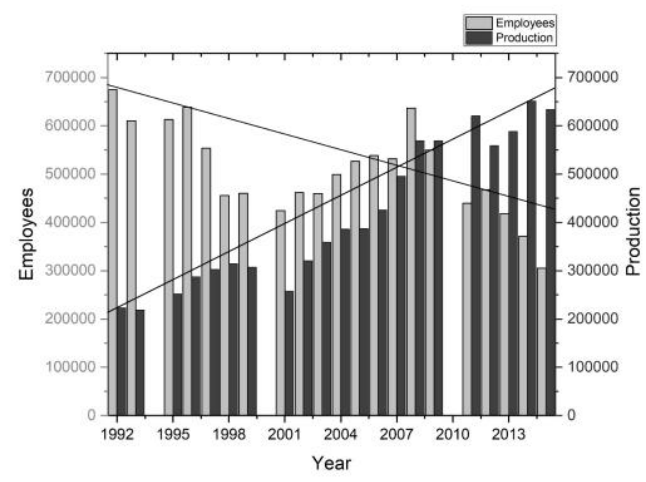

Figure 2. Evolution of the amount of sugar cane produced and the number of employees in this crop. Source: Based on data from UNICA (2016) and IBGE (2019). 
As the purpose of this article is to evaluate the impact of agricultural modernization on the sugarcane labor market, all employees in this activity sector were divided into two subgroups, so that a subset represents the non-skilled labor force, and is composed of workers performing agricultural operations as brush cutters, rural workers, lanyard, agricultural foreman, handyman; and the other subgroup includes the so-called "skilled" workforce, since it involves people who worked as supervisor, administrator, technician, tractor driver, and others.

In 1992, this skilled labor corresponded to only $10.2 \%$ of the total employees in the sugarcane field. In 2015 this proportion increased to $34.7 \%$. No other agricultural activity had this performance over time, although soybean cultivation already had a high proportion of skilled workers in the 1990s, as shown in Figure 3 below.
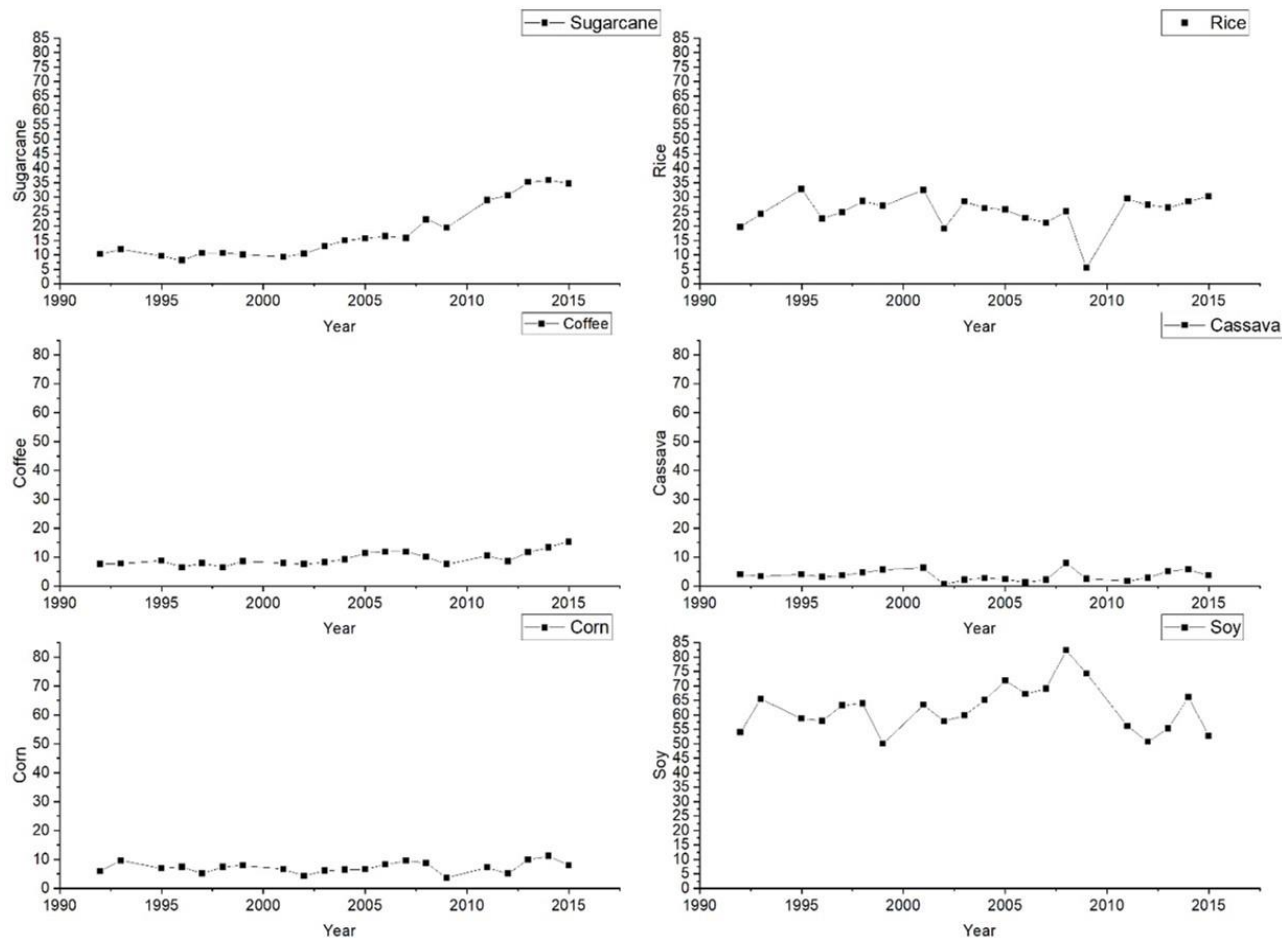

Figure 3. Proportion of employees ${ }^{(1)}$ skilled in agriculture, sugarcane and other activities. Brazil, 1992 and 2015. Source: Prepared using the data of the (IBGE, 2019); ${ }^{(1)}$ Only people with a positive value declaration for the main work income.

Another highlight is that there has been a large reduction in the number of employees in sugarcane cultivation between 1992 and 2007. However, there is a different trend among the skilled ones since there was a reduction of $67 \%$ of unskilled employees (the index number, base $1992=100$, at the end of the series shown in Figure 4 explains this), the increase was $53 \%$ among the skilled workers.

Oliveira (2009) pointed out that, using PNAD data from 1992 to 2007, the harvest mechanization or any other stage of the product process in sugarcane or other crops alters the employee's profile, as it creates opportunities for other workers such as tractor drivers, drivers, mechanics, harvester and agricultural machinery operators, agricultural technicians, agronomists, among others, but it also reduces the demand of low-level employees. 


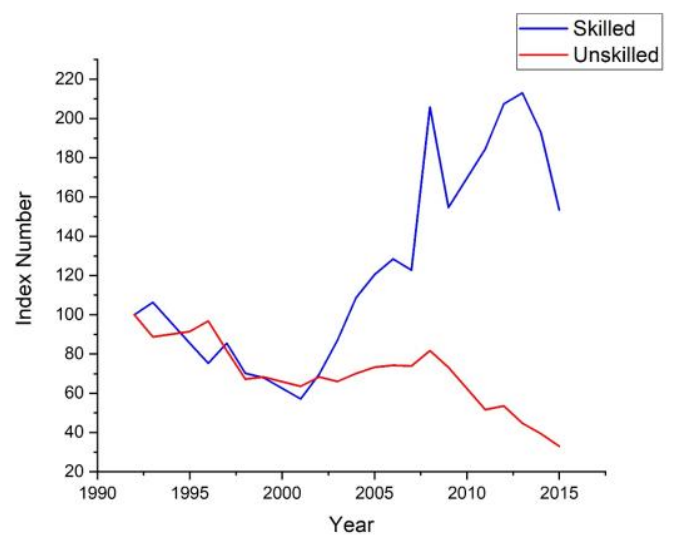

Figure 4. Evolution of the number of employees ${ }^{(1)}$ skilled and unskilled in sugarcane cultivation, Brazil, 1992 to 2015. Source: Prepared using the data of the (IBGE, 2019); (1) Only people with a positive value declaration for the main work income.

Despite the negative employment evolution in sugarcane farming between 1992 and 2015, the quality of employment has grown and thus we observed improvements in educational indicators. Figure 5 shows that, in 1992, the average schooling years of workers in the sugarcane activity was only 1.9 years, to 5.8 years in 2015 . However, we emphasize that with the advances and efforts of modernization in the agricultural sector, besides the organizational changes that seek to obtain competitive gains, the average schooling of the worker is still very low in Brazil. The agricultural sector is one of the few activity sectors that still employ people with extremely low levels of education, including illiterate workers.
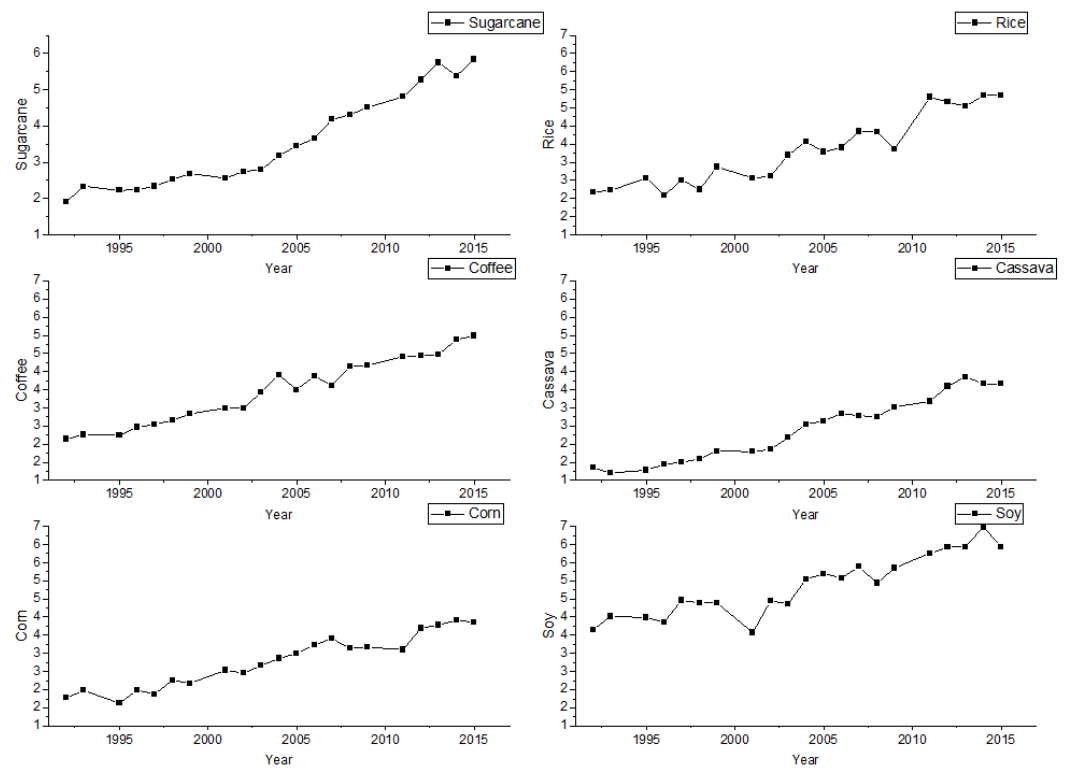

Figure 5. Evolution of the average years of studies of employed persons ${ }^{(1)}$ in agriculture, in sugarcane plantations and in other activities, Brazil, 1992 to 2015. Source: Prepared using the data of the (IBGE, 2019); (1)Only people with a positive value declaration for the main work income. 


\subsection{Econometric findings}

Table 1 shows our findings obtained for the equation of wage differentials in sugarcane and other crops using the Heckman procedure (Heckman, 1979) in two stages. The marginal effects of the variables estimated in the probit model (first stage) are not constant, which does not allow such coefficients to be interpreted directly (Hoffmann \& Kassouf, 2005). For this reason, we did not present them in this table.

The basic idea of this procedure is based on the fact that the economic agent has a reserve wage, and which below this agent does not accept to participate in the labor market. Thus, the choice to participate in the labor market is conducted by a decision rule that makes the agent accept the salary offered. The decision-making rule for market participation is defined as follows: the individual participates in the labor force whenever the market wage exceeds its reserve wage (Scorzafave \& Menezes-Filho, 2001; Sachsida et al., 2004).

Table 1. Estimated salary equation for employees in agriculture, sugarcane and other activities. Brazil, 1992 to 2015.

\begin{tabular}{|c|c|c|}
\hline Variable & Coeffic & \\
\hline Constant & 5.06461 & * \\
\hline Female person (base: male) & -0.33688 & * \\
\hline Age & & \\
\hline Age/ 10 & 0.42466 & * \\
\hline$(\mathrm{Age} / 10)^{2}$ & -0.04292 & * \\
\hline Basic education: (less than 1 year of study) & & \\
\hline From 1 to 3 years of study & 0.12632 & * \\
\hline From 4 to 7 years of study & 0.36940 & * \\
\hline From 8 to 10 years of study & 0.62248 & * \\
\hline From 11 to 14 years of study & 0.92892 & * \\
\hline 15 years or more of study & 1.67311 & * \\
\hline Race (Base: white) & & \\
\hline Black or brown & -0.12898 & * \\
\hline Asian & 0.17760 & * \\
\hline Indigenous & -0.09425 & * \\
\hline Region (base: Northeast) & & \\
\hline North ${ }^{(1)}$ & 0.23756 & * \\
\hline South & 0.33906 & * \\
\hline Midwest & 0.30501 & * \\
\hline Sao Paulo & 0.37597 & * \\
\hline Sector of activity (base: sugarcane) & & \\
\hline All other crops ${ }^{(2)}$ & -0.37540 & * \\
\hline Coffee & -0.27681 & * \\
\hline Cassava & -0.55414 & * \\
\hline Corn & -0.76408 & * \\
\hline Soy & 0.07318 & * \\
\hline Rice & -0.14588 & \\
\hline Weekly working time (basis: 15 to 39 hours) & & \\
\hline 40 to 44 hours & 0.40583 & * \\
\hline 45 to 48 hours & 0.38954 & * \\
\hline 49 hours or more & 0.47381 & * \\
\hline Informal employee (basis: formal) & -0.25436 & * \\
\hline Temporary worker (basis: permanent) & -0.03378 & * \\
\hline Minimum wage real value (divided by 100 ) & 0.02628 & * \\
\hline Lambda & -0.92 & \\
\hline Wald test of eq. independent (prob.) & $<0.00$ & \\
\hline Number of observations & 3.403. & \\
\hline
\end{tabular}

If we consider that wage depends only on the labor supply, excluding the role of job search, the sample may present selection bias. However, by adopting the Heckman's 
estimator, the wage equation is associated with the selection equation, which in turn defines the decision of the individual to participate in the labor market.

Considering the individuals employed and those who were part of the Economically Active Population (EAP) but who were unemployed, from 1992 to 2015, the sample contained information of $3,403,976$ individuals, of which $84 \%$ were employed in the reference survey weeks of the respective PNADs.

In fact, because the sample consists of a high percentage of workers with incomes, it could indicate that sample selectivity might not be a problem in this study, which would allow the wage equations to be estimated by the classical regression methods. However, the maximum likelihood ratio test $(<.00000)$ for the rho statistic, which measures the correlation between the selection equation and the wage determination, indicates that there is a sample selection bias in the model, implying that the proposed Heckman procedure (1979) is preferable to the Ordinary Least Squares estimator without correction. However, we use panel data methods as an alternative for evaluating the wage determinants of employees (wage earners).

The results obtained for almost all the coefficients of the model are significant at $1 \%$, including the estimate of the inverted Mills ratio $(\lambda)$. After considering the effects of the other variables, the income of the employees in the selected crops or the rest of the agriculture is significantly smaller in comparison with the average sugarcane wage, except for the average wage obtained in the soybean crops. Negative estimates of the coefficients of these variables attest to this result. This is an important finding, because although the sugarcane segment is criticized for exploiting the labor force (Alves, 2007, Balsadi, 2010, among many others), it is undeniable that there are advances, with improvements in the quality of employment, and with clear repercussions on the wages of employees in this activity.

As is generally observed in income equations, differences between genders are captured because, according to the negative sign of the coefficient of the gender variable, a lower wage is expected for the female population in relation to that obtained by the male population. As for the education variable, as one might expect, the higher the schooling level, the higher the level of the expected salary. The coefficients obtained for skin color or race of the wage earners in the Brazilian economy also reflect lower gains expected for black and brown skin people color compared to white people, after considering the effects of the other variables in the model. The effect of informality is also captured since after controlling the effects of the other explanatory variables included in the regression, the employee without a work permit has lower wage when compared to the employee with a portfolio record.

Table 2 shows the results of the coefficients of the regression equations using pooled, random effects and fixed effects for the information of wage earners in the Brazilian agricultural sector. We note that almost all estimates of the pooled regression coefficients or the fixed effect and random effect models are significant at the $1 \%$ level. Note that these results are similar to those obtained by the regression equation based on the Heckman procedure (see Table 1). This is an important methodological finding because it shows that the Heckman procedure and the pooled regression present similar estimates.

However, although the pooled coefficients are significant, they must be biased and inconsistent, since they certainly include non-observable characteristics such as aptitude, motivation, entrepreneurship, skill, and other features, that must be related to the explanatory variables of the model. In fact, considering the unobserved heterogeneity of the labor force employed in the various activity branches, the same regression model was also estimated using the fixed effects methodologies and random effects for the pseudo panel data selected for this study.

We applied the Breusch-Pagan Lagrange Multiplier test, which confirms the idea that the estimates obtained by the pooled regression are skewed and inconsistent due to the 
omission of the relevant variable. Subsequently, we applied the Hausman specification test, and it was observed that by adopting the fixed effects regression (see 2nd and 3rd columns) compared to the pooled regression (see 1st and 2nd columns), almost all the coefficients of the dummies used in the model were reduced, except for the coefficients of dummies that capture the effect of schooling on the level of income. This shows an important characteristic of the existing unobserved heterogeneity.

This study shows that the fixed-effect regression captures the same trends as the OLS model using the Heckman procedure. Regional differences were again captured, with all considered regions showing positive coefficients, indicating that higher wages are expected for agricultural workers in these regions compared to workers in the Northeast region. The Southeast tends to pay the highest wages. The difference in expected income, after controlling the effects of the other explanatory variables included in the regression, is $35.7 \%$ for this federation unit when compared to the northeastern region.

Our main result demonstrated that income differentials in the agricultural segment were maintained, thus employees in agriculture as a whole and in coffee, corn, cassava, and rice crops tend to earn less than those employed in sugarcane farming. After considering the effects of the other variables of the model, the differentials associated to the income of employees in the activity sectors highlighted in this study compared to the average wage in the sugarcane crop are: -4.08 in agriculture sector; -4.8 in coffee crop, -16.03 in cassava, -20.92 in corn, +16.17 in Soy and -2.99 in rice crop. This finding helps the argument against criticism that mechanization of the sugarcane sector has only generated fewer jobs without raising wages.

Finally, we highlight: The sugarcane labor market has eliminated many jobs in the last 20 years, more than in other agricultural activities, mainly due to the increased use of technology by the sector; there is a growth of jobs with more stable employment relationships, and also increasing the employed workers real earnings, not only in the sugarcane industry but also in the other agricultural activities investigated; however, our econometric models show that the wages of people employed in enterprises in which the main activity is sugarcane production is the highest, when compared to the wages obtained in the other selected crops; the main income determinants are education, discrimination against women, regions.

Table 2. Estimated wage equations according to the panel data models for employees in agriculture, sugarcane and other activities. Brazil, 1992 to 2015.

\begin{tabular}{|c|c|c|c|c|c|c|c|c|c|}
\hline \multirow[b]{2}{*}{ Variable } & \multicolumn{3}{|c|}{ Pooled regression } & \multicolumn{3}{|c|}{ Fixed Effect } & \multicolumn{3}{|c|}{ Random Effect } \\
\hline & Coefficient & $\begin{array}{l}\text { Margin } \\
\text { Effect }\end{array}$ & & Coefficient & $\begin{array}{l}\text { Margina } \\
\text { Effect }\end{array}$ & & Coefficient & $\begin{array}{l}\text { Margin } \\
\text { Effect }\end{array}$ & nal \\
\hline Constant & 5.2203 & & * & 4.7497 & & * & 4.6235 & & * \\
\hline Female (base: male) & -0.1959 & -17.79 & * & -0.2170 & -19.51 & * & -0.1907 & -17.36 & * \\
\hline \multicolumn{10}{|l|}{$\begin{array}{l}\text { Basic education: (less than } 1 \\
\text { year of study) }\end{array}$} \\
\hline $\begin{array}{l}\text { From } 1 \text { to } 3 \text { years of } \\
\text { schooling }\end{array}$ & 0.0319 & 3.25 & * & 0.0646 & 6.67 & * & 0.0273 & 2.77 & * \\
\hline $\begin{array}{l}\text { From } 4 \text { to } 7 \text { years of } \\
\text { schooling }\end{array}$ & 0.0854 & 8.91 & * & 0.1374 & 14.73 & * & 0.0749 & 7.78 & * \\
\hline $\begin{array}{l}\text { From } 8 \text { to } 10 \text { years of } \\
\text { schooling }\end{array}$ & 0.1415 & 15.20 & * & 0.2053 & 22.78 & * & 0.1240 & 13.20 & * \\
\hline $\begin{array}{l}\text { From } 11 \text { to } 14 \text { years of } \\
\text { schooling }\end{array}$ & 0.3407 & 40.59 & * & 0.3817 & 46.47 & * & 0.3220 & 38.00 & * \\
\hline 15 years or more of schooling & 1.0823 & 195.16 & * & 1.0843 & 195.74 & * & 1.0607 & 188.85 & 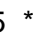 \\
\hline
\end{tabular}


Table 2. Continued...

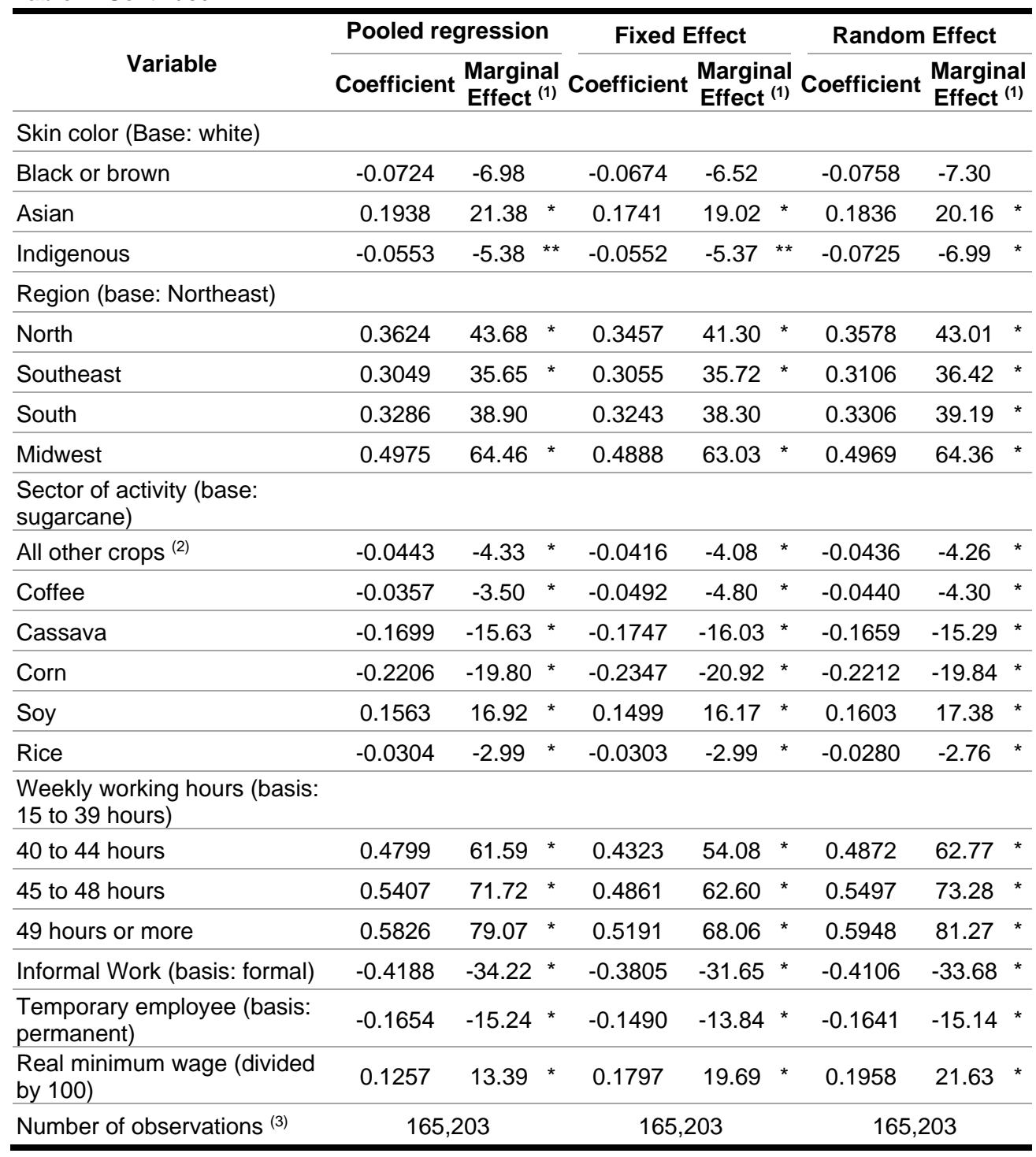

Source: Prepared using (IBGE, 2019). Notes: * shows that the result is significant at the level of $1 \%$. (1) The exclusive rural area of RO, AC, AM, RR, PA, and AP; (2) Other crop activities, except sugarcane, coffee, manioc, corn, soybeans, and rice; (3) The number of observations is smaller when compared to the model using the Heckman procedure, because here only the observations of employees in agriculture were considered, whereas in the first model it was necessary to use the information of the employed and unoccupied in the economy in general to obtain the estimates of the first stage.

\section{Final remarks and some recommendations}

From a methodological point of view, our most important result is that the Mincer's wage equation suggests some convergence between the estimates of the Heckman and fixed effects panel models, which both are highly significant. Estimates of the econometric models show that the wages of persons employed in sugarcane production enterprises are the highest compared to other selected crops, except for soybean.

Additionally, we highlight the income determinants of skilled and un-skilled agricultural workers: the importance of schooling, discrimination against women, regional differences, such as between the Southeast and Central West, indicating that wages are strongly 
associated with the different techniques and productivity levels between groups of persons and Brazilian regions.

Our study shows that, despite the decrease in employment in sugarcane plantations in the period between 1992 and 2015, the quality of employment increased and together with it improvements in educational indicators can be observed. Although we expect these changes to continue over the next years, we argue that public and private policies are required to complement formal education and (re)qualification of workers in order to support the trend of qualitative improvement in labor relations.

If these policies do not take place, many workers will lose their jobs due to technological advances, which are currently being adopted in the Brazilian agricultural sector. Workers will also face problems to relocate to other work activities, given their low professional qualification level. In this sense, we argue that education plays a fundamental role in the qualification of individuals, as it contributes to the formation of a workforce capable of generating more productivity, higher salaries and better adaptation to the labor market. Thus, improving education is also essential to reduce income inequality in Brazilian agriculture.

Finally, some limitations of this study presented here are expected to open multiple avenues for future research. First, although the study analyzed several years (from 1995 to 2015), future studies are encouraged to examine events that may affect employment, such as the crisis that has affected the sugarcane sector since 2007. Second, future researchers can also examine the phenomenon in other countries and sectors. Third, future studies can focus on the role of institutions and training programs to increase employment and income in the sugarcane sector.

\section{Acknowledgements}

The first author would like to express his gratitude for the financial support of Coordenação de Aperfeiçoamento de Pessoal de Nível Superior (CAPES) (Process no․ 88887.161388/2017-00), the Lions-Club-Förderpreis (Stuttgart/Germany) and the Friedrich-Naumann-Stiftung für die Freiheit.

\section{References}

Agra Europe. (2010). F.O. Licht's Sugar \& Ethanol Brazil. World Ethanol \& Biofuels Reports. Retrieved in 2016, January 13, from http://www.agra-net.com

Alves, F. (2007). Migração de trabalhadores rurais do Maranhão e Piauí para o corte de cana em São Paulo. In J. R. Novaes \& F. Alves (Orgs.), Migrantes: trabalho e trabalhadores no complexo agroindustrial canavieiro (os heróis do agronegócio brasileiro) (pp. 21-54). São Carlos: EDUFSCAR.

Arbache, J. S. (2000). Determinação e diferencial de salários no Brasil. In R. Fontes \& M. A. Arbex (Org.), Desemprego e mercado de trabalho: ensaios teóricos e empíricos (pp. 125-180). Viçosa: UFV.

Balsadi, O. V. (1996). Condicionantes da renda das pessoas ocupadas na agricultura paulista em 1981 e 1990. Informações Econômicas, 26(8), 41-49.

Balsadi, O. V. (2010). Mercado de trabalho assalariado na cultura da cana-de-açúcar no período 1992-2006. Revista de Economia Agrícola, 57(1), 91-110.

Brasil. Ministério da Economia. Secretaria de Comércio Exterior - SECEX. (2016). Dados estatísticos. Retrieved in 2016, January 8, from http://www.mdic.gov.br/ 
Cás, F. R., \& Ferreira, L. R. (2007). Uma análise do diferencial entre salários rurais no estado de São Paulo: 1980 / 2006. In Anais do Congresso Brasileiro de Economia e Sociologia Rural (Vol. 45, 16 p.). Brasília: SOBER. 1 CD-ROM.

Certo, S. T., \& Semadeni, M. (2006). Strategy research and panel data: evidence and implications. Journal of Management, 32(3), 449-471.

Corrêa, A. M. C. J. (1998). Distribuição de renda e pobreza na agricultura brasileira (260p.). Piracicaba: UNIMEP.

Corseuil, C. H., \& Foguel, M. N. (2002). Uma sugestão de deflatores para rendas obtidas a partir de algumas pesquisas domiciliares do IBGE (Nota Técnica, pp. 57-64). Brasília: IPEA.

Cunha, M. S. (2008). Os empregados da agricultura brasileira: diferenciais e determinantes salariais. Revista de Economia e Sociologia Rural, 46(3), 597-621.

Deaton, A. (1985). Panel data from time series of cross-sections. Journal of econometrics, 30(1-2), 109-126.

Ferraz, D., Oliveira, F. C. R., \& Assumpção, M. R. P. (2019). Análise do impacto de mudanças institucionais sobre a produção de açúcar no Brasil entre 1980 a 2015. Exacta, 17(1), 127145. http://dx.doi.org/10.5585/ExactaEP.v17n1.8108.

Figueira, S. R. F., Perosa, B. B., \& Belik, W. (2013). Impacto da desregulamentação e da concorrência. AgroANALYSIS, 33(3), 23-25.

Greene, W. H. (2011). Econometric analysis. London: Pearson Education.

Heckman, J. J. (1979). Sample selection bias as a specification error. Econometrica: Journal of the econometric society, 153-161.

Hoffmann, R., \& Kassouf, A. L. (2005). Deriving conditional and unconditional marginal effects in log earnings equations estimated by Heckman's procedure. Applied Economics, 37(11), 13031311.

Horrace, W. C., \& Oaxaca, R. L. (2006). Results on the bias and inconsistency of ordinary least squares for the linear probability model. Economics Letters, 90(3), 321-327.

Instituto Brasileiro de Geografia e Estatística - IBGE. (2006). Pesquisa nacional por amostra por domicílios 2006. Rio de Janeiro: IBGE.

Instituto Brasileiro de Geografia e Estatística - IBGE. (2019). Pesquisa nacional por amostra por domicílios 2019. Rio de Janeiro: IBGE.

Moraes, M. (2002). Desregulamentação da agroindústria canavieira: novas formas de atuação do Estado e desafios do setor privado. In M. A. F. D. Moraes \& P. F. A. Shikida, Agroindústria canavieira no Brasil: evolução, desenvolvimento e desafios (21-42). São Paulo: Atlas.

Moraes, M. A. F. D. (2007a). Indicadores do mercado de trabalho do sistema agroindustrial da cana-de-açúcar do Brasil no período 1992-2005. Estudos Econômicos (São Paulo), 37(4), 875-902.

Moraes, M. A. F. D. (2007b). O mercado de trabalho da agroindústria canavieira: desafios e oportunidades. Economia Aplicada, 11(4), 605-619.

Moraes, M. A. F. D., \& Zilberman, D. (2014). Production of ethanol from sugarcane in brazil: from state intervention to a free market (Vol. 43). USA: Springer Science \& Business Media.

Mori, J. S. (2008). Diferenciais de salários nas atividades agrícolas brasileiras: aspectos estruturais e determinantes regionais (Dissertação em mestrado). Escola Superior de Agricultura "Luiz de Queiroz", Universidade de São Paulo, Piracicaba.

Neves, M. F., Gray, A. W., \& Bourquard, B. A. (2016). Copersucar: a world leader in sugar and ethanol. International Food and Agribusiness Management Review, 19(2), 1-34.

Ney, M. G., \& Hoffmann, R. (2003). Desigualdade de renda na agricultura: o efeito da posse da terra. Economía, 4(1), 85-112. 
Novaes, M. R., Rudorff, B. F. T., de Almeida, C. M., \& Aguiar, D. A. (2016). Análise espacial da redução da queima na colheita da cana-de-açúcar perspectivas futuras ao cumprimento do protocolo agro-ambiental. Engenharia Agrícola, 31(3)

Oliveira, F. C. R. (2009). Ocupação, emprego e remuneração na cana-de-açúcar e em outras atividades agropecuárias no Brasil, de 1992 a 2007 (Dissertação de mestrado). Escola Superior de Agricultura "Luiz de Queiroz", Universidade de São Paulo, Piracicaba.

Oliveira, F. C. R., \& Hoffmann, R. (2011). Determinantes dos salários dos empregados na lavoura de cana de açúcar e em outras atividades agropecuárias no Brasil. Revista de Economia Agrícola, 58(2), 41-56.

Ramos, P., \& Belik, W. (2019). Intervenção estatal e a agroindústria canavieira no Brasil. Revista de Economia e Sociologia Rural, 27(2), 197-214.

Sachsida, A., Loureiro, P. R. A., \& de Mendon, M. J. C. (2004). Um estudo sobre retorno em escolaridade no Brasil. Revista Brasileira de Economia, 58(2), 249-265.

Sao Paulo. (2002). Lei Estadual n 11.241, de 19 de setembro de 2002. Dispõe sobre a eliminação gradativa da queima da palha da cana-de-açúcar e dá providências correlatas. São Paulo (SP): Diário Oficial do Estado de São Paulo.

São Paulo. (2007). Protocolo agroambiental do setor sucroalcooleiro paulista, de 04 de junho de 2007. Retrieved in 2018, May 25 from http://dobuscadireta.imprensaoficial.com.br/default.aspx?DataPublicacao=20020920\&Cadern $0=$ DOE-I\&NumeroPagina $=2$.

Scorzafave, L. G., \& Menezes-Filho, N. A. (2001). Participação feminina no mercado de trabalho brasileiro: evolução e determinantes. Pesquisa e Planejamento Econômico, 11(3), 441-478.

Shikida, P. F. A., Azevedo, P. F., \& Freitas Vian, C. E. (2010). Uma análise das capacidades tecnológicas da agroindústria canavieira em Minas Gerais. Revista de Economia e Agronegócio, 8(2), 251-278.

União da Indústria de Cana de Açúcar - UNICA. (2016). Unicadata. Retrieved in 2016, January 8 , from http://www.unica.com.br/ 